\title{
Sporosarcina contaminans sp. nov. and Sporosarcina thermotolerans sp. nov., two endospore-forming species
}

\author{
Correspondence \\ Peter Kämpfer \\ peter.kaempfer@umwelt. \\ uni-giessen.de
}

\author{
P. Kämpfer, ${ }^{1}$ E. Falsen, ${ }^{2}$ N. Lodders $^{1}$ and P. Schumann ${ }^{3}$ \\ ${ }^{1}$ Institut für Angewandte Mikrobiologie, Justus-Liebig-Universität Giessen, D-35392 Giessen, Germany \\ ${ }^{2}$ Culture Collection University Göteborg, Department of Clinical Bacteriology, S-41346 Göteborg, \\ Sweden \\ ${ }^{3} \mathrm{DSMZ}$ - Deutsche Sammlung von Mikroorganismen und Zellkulturen, D-38124 Braunschweig,
Germany
}

The taxonomic positions of two Gram-positive, endospore-forming rods, strains CCUG $53915^{\top}$ and CCUG $53480^{\top}$, isolated from an industrial clean-room floor and from a human blood sample, respectively, were studied. 16S rRNA gene sequence similarity studies revealed that both isolates clearly clustered with Sporosarcina species. Strain CCUG $53915^{\top}$ was most closely related to Sporosarcina koreensis and Sporosarcina soli, showing 99.4 and $99.2 \% 16 \mathrm{~S}$ rRNA gene sequence similarities to the type strains of these species, respectively. Strain CCUG $53480^{\top}$ showed the highest $16 \mathrm{~S}$ rRNA gene sequence similarities to the type strains of $S$. koreensis $(98.7 \%)$ and Sporosarcina saromensis (98.6\%). Strains CCUG $53915^{\top}$ and CCUG $53480^{\top}$ had peptidoglycan type A4 $\alpha$ L-Lys-D-Glu. The quinone systems of both strains were composed predominantly of menaquinone MK-7, with small amounts of MK-8. The polar lipid profiles of both strains consisted of phosphatidylglycerol, diphosphatidylglycerol, phosphatidylethanolamine and three unidentified phospholipids. The fatty acid profiles, which comprise anteiso- and iso-branched fatty acids, supported affiliation of the two isolates to the genus Sporosarcina. The results of physiological and biochemical tests and DNA-DNA hybridization data allowed a clear phenotypic and genotypic differentiation of both strains from the most closely related Sporosarcina species. For this reason, it is proposed that strains CCUG $53915^{\top}$ (=DSM 22204 ${ }^{\top}$ ) and CCUG $53480^{\top}$ (=DSM $22203^{\top}$ ) represent two novel species in the genus Sporosarcina, with the names Sporosarcina contaminans sp. nov. and Sporosarcina thermotolerans sp. nov., respectively.
The genus Sporosarcina was described by Kluyver \& van Niel (1936) and comprises several Gram-positive, endospore-forming rods that have been isolated from various environmental and also clinical habitats (Claus et al., 1983; Yoon et al., 2001; Reddy et al., 2003; An et al., 2007; Krishnamurthi et al., 2009). The genus is characterized by having L-lysine as the diagnostic amino acid in the peptidoglycan and MK-7 as the characteristic menaquinone. In this study, the phenotypic and genotypic properties of two novel Sporosarcina strains isolated from different samples are described.

The GenBank/EMBL/DDBJ accession numbers for the 16S rRNA gene sequences of strains CCUG $53915^{\top}$ and CCUG $53480^{\top}$ are FN298444 and FN298445, respectively.

The cellular fatty acid compositions of the type strains of members of the genus Sporosarcina are available with the online version of this paper.
Strain CCUG $53915^{\mathrm{T}}$ was isolated as a contaminant from an industrial clean-room floor in Göteborg, Sweden, and strain CCUG $53480^{\mathrm{T}}$ was isolated from a human blood sample of a 54-year-old woman in Göteborg, Sweden. Both strains were isolated on blood agar at $37^{\circ} \mathrm{C}$, but maintained on tryptone soy agar (TSA; Oxoid) at $30{ }^{\circ} \mathrm{C}$.

Gram staining was performed as described by Gerhardt et al. (1994). Cell morphology was examined with a Zeiss light microscope at $\times 1000$ magnification using cells that had been grown for $24 \mathrm{~h}$ at $30{ }^{\circ} \mathrm{C}$ on TSA. Cell morphology data are given in the formal species description.

The 16S rRNA gene was analysed as described previously (Kämpfer et al., 2003). PCR amplification of the 16S rRNA gene was carried out with the primer pair $27 \mathrm{~F}$ (5'-GAGTTTGATCMTGGCTCAG) and MR 1492R (5'ACGGYTACCTTGTTACGACTT) (Lane, 1991). For sequen- 
cing, standard sequencing primers for the 16S rRNA gene were used. The $16 \mathrm{~S}$ rRNA gene sequences of strains CCUG $53915^{\mathrm{T}}$ and CCUG $53480^{\mathrm{T}}$ were continuous stretches of 1463 and $1420 \mathrm{bp}$, respectively. Phylogenetic analysis was performed using the ARB software package (version December 2007; Ludwig et al., 2004) and the corresponding SILVA ssuRef 95 database (version July 2008; Pruesse et al., 2007). Trees were reconstructed using the maximum-likelihood method with FASTDNAML (Olsen et al., 1994) and $50 \%$ conservatory filter (only alignment columns in which the frequency of the most abundant nucleotide was equal to or above $50 \%$ were included into the calculation). Tree topology was further tested without filters. Tree topologies showed similar groupings regarding CCUG $53915^{\mathrm{T}}$, CCUG $53480^{\mathrm{T}}$ and their nearest relatives. A maximum-likelihood tree is shown in Fig. 1. A tree reconstructed with the neighbour-joining method showed a similar result (data not shown). The $16 \mathrm{~S}$ rRNA gene sequences of the strains were compared by distance calculations (distance options according to the Kimura-2 model) using the software package MEGA version 4.0 (Tamura et al., 2007).

16S rRNA gene sequence similarity calculations indicated that the closest relatives of strain CCUG $53915^{\mathrm{T}}$ were Sporosarcina koreensis $\mathrm{F}^{\mathrm{T}}{ }^{\mathrm{T}}$ (GenBank accession no. DQ073393) with $99.4 \%$ similarity and Sporosarcina soli $\mathrm{I}^{\mathrm{T}}{ }^{\mathrm{T}}$ (GenBank accession no. DQ073394) with $99.2 \%$ similarity. The closest relatives of strain CCUG $53480^{\mathrm{T}}$ were S. koreensis $\mathrm{F} 3^{\mathrm{T}}$ with $98.7 \%$ similarity and Sporosarcina saromensis $\mathrm{HG} 645^{\mathrm{T}}$ (GenBank accession no. AB243859) with $98.6 \%$ similarity.

The peptidoglycan of strains CCUG $53915^{\mathrm{T}}$ and CCUG $53480^{\mathrm{T}}$ grown in tryptic soy broth at $28^{\circ} \mathrm{C}$ for 1 day was isolated after disruption of the cells by shaking with glass beads and subsequent trypsin digestion according to the method of Schleifer (1985). The amino acids and peptides in the cell-wall hydrolysates were analysed by twodimensional ascending TLC on cellulose plates by using previously described solvent systems (Schleifer, 1985). The molar ratios of the amino acids were determined by GC (GC 14A; Shimadzu) and GC-MS (320-MS Quadrupole GC/MS; Varian) of $N$-heptafluorobutyryl amino acid isobutyl esters (MacKenzie, 1987; Groth et al., 1996). The hydrolysate $\left(4 \mathrm{M} \mathrm{HCl}, 100{ }^{\circ} \mathrm{C}, 16 \mathrm{~h}\right)$ of the purified peptidoglycan of strains CCUG $53915^{\mathrm{T}}$ and CCUG $53480^{\mathrm{T}}$ contained the amino acids lysine, alanine and glutamic acid in molar ratios of approximately $1.0: 1.7: 2.4$ and $1.0: 1.3: 2.0$, respectively. The peptides L-Ala-D-Glu and L-Lys-D-Ala were detected in the partial hydrolysate $\left(4 \mathrm{M} \mathrm{HCl}, 100{ }^{\circ} \mathrm{C}, \quad 0.75 \mathrm{~h}\right)$ of the peptidoglycan. Dinitrophenylation according to Schleifer (1985) revealed that Glu represents the $\mathrm{N}$ terminus of the interpeptide bridge. These data suggest that the peptidoglycan of strains CCUG $53915^{\mathrm{T}}$ and CCUG $53480^{\mathrm{T}}$ is of type A4 $\alpha$ L-Lys-DGlu (Schleifer \& Kandler, 1972), which is also found in other members of the genus Sporosarcina (Reddy et al., 2003; Yoon et al., 2001; Yu et al., 2008; Kwon et al., 2007). Menaquinones and polar lipids were extracted from cells of strains CCUG $53915^{\mathrm{T}}$ and CCUG $53480^{\mathrm{T}}$ grown in tryptic soy broth at $28{ }^{\circ} \mathrm{C}$ for 1 day. Menaquinones were analysed (Groth et al., 1996) after extraction as described by Collins et al. (1977) and polar lipids were determined according to Minnikin et al. (1979). Strains CCUG $53915^{\mathrm{T}}$ and CCUG $53480^{\mathrm{T}}$ contained the menaquinones MK-7 and MK-8 in the ratios $98: 2\left(\right.$ CCUG $53480^{\mathrm{T}}$ ) and $96: 4\left(\right.$ CCUG $53915^{\mathrm{T}}$ ) and the phospholipids phosphatidylglycerol, diphosphatidylglycerol, phosphatidylethanolamine and three unidentified phospholipids.

Fatty acid analysis was performed according to Kämpfer \& Kroppenstedt (1996). The fatty acid profiles of both strains were very similar to those of closely related Sporosarcina species (see Supplementary Table S1, available in IJSEM Online). A typical fatty acid profile consisting of mainly anteiso- and iso-branched fatty acids was found.

Results of the comparative physiological characterization of all Sporosarcina species are given in Table 1. Strains CCUG $53915^{\mathrm{T}}$ and CCUG $53480^{\mathrm{T}}$ were also tested with the API

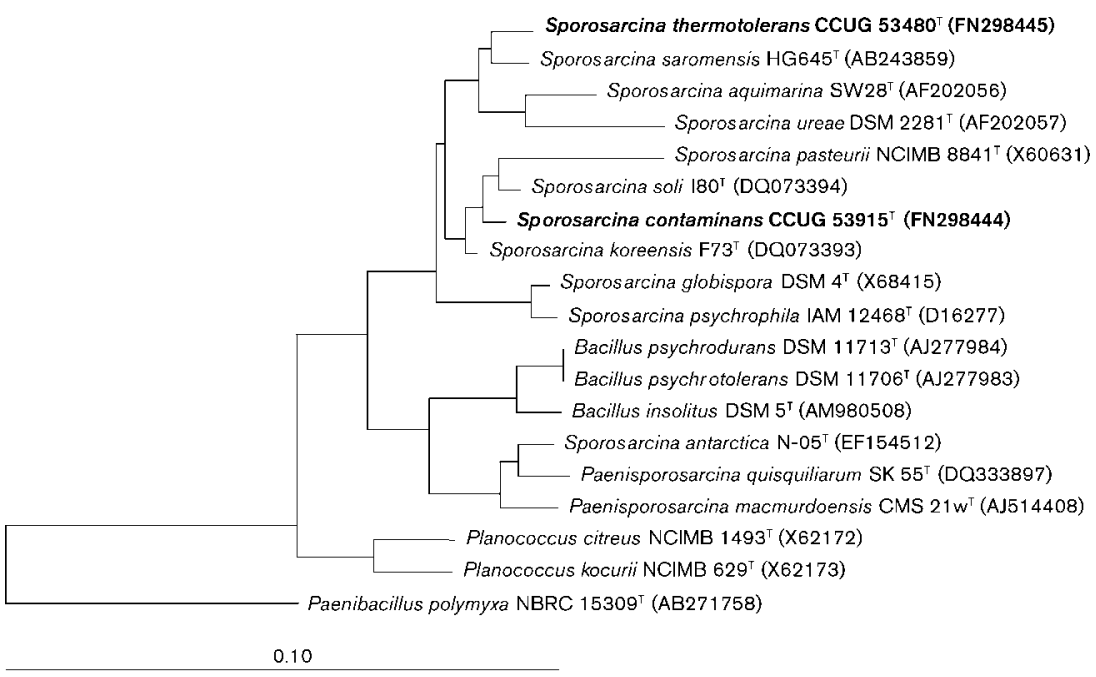

Fig. 1. Phylogenetic analysis based on $16 \mathrm{~S}$ rRNA gene sequences available from GenBank/EMBL (accession numbers are given in parentheses). The phylogenetic tree was constructed using the ARB software package (version December 2007; Ludwig et al., 2004) and the corresponding SILVA SSURef 95 database (version July 2008; Pruesse et al., 2007). Tree building was performed using the maximum-likelihood method with FASTDNAML (Olsen et al., 1994) without conservatory filter. Bar, 0.10 nucleotide substitutions per nucleotide position. 
Table 1. Differential phenotypic and physiological characteristics of Sporosarcina species

Taxa: 1, CCUG 53915 ; 2, S. koreensis $\mathrm{F}_{3}^{\mathrm{T}}$; 3, S. soli $\mathrm{I} 80^{\mathrm{T}}$; 4, S. macmurdoensis (data from Reddy et al., 2003); 5, S. aquimarina (Yoon et al., 2001); 6, S. globispora (Nakamura, 1984; Rüger, 1983); 7, S. psychrophila (Nakamura, 1984); 8, S. pasteurii (Yoon et al., 2001); 9, S. ureae (Claus \& Fahmy, 1986); 10, CCUG $53480^{\mathrm{T}}$; 11, S. saromensis $\mathrm{HG}_{645^{\mathrm{T}}}$ (data from An et al., 2007). Data for taxa 1, 2, 3, 10 and 11 are based on results for the type strain. All of the taxa are positive for catalase activity. +, Positive; -, negative; w, weak; NA, data not available.

\begin{tabular}{|c|c|c|c|c|c|c|c|c|c|c|c|}
\hline Characteristic & 1 & 2 & 3 & 4 & 5 & 6 & 7 & 8 & 9 & 10 & 11 \\
\hline Cell shape $\dagger$ & $\mathrm{R}$ & $\mathrm{R}$ & $\mathrm{R}$ & $\mathrm{R}$ & $\mathrm{R}$ & $\mathrm{R}$ & $\mathrm{R}$ & $\mathrm{S}$ & S & $\mathrm{R}$ & $\mathrm{R}$ \\
\hline Motility & + & + & - & - & + & + & + & + & + & - & + \\
\hline $\mathrm{NaCl}$ tolerance $(\%)$ & 10 & 7 & 5 & 3 & 13 & 5 & 2 & 10 & 3 & 3 & 9 \\
\hline Optimum pH & $7-8$ & 7 & 8 & 7 & $6.5-7.0$ & 7 & 7 & 9 & 7 & 7 & 6.5 \\
\hline 5 and $10{ }^{\circ} \mathrm{C}$ & - & - & - & + & + & + & + & NA & NA & $\mathrm{w}$ & + \\
\hline $30{ }^{\circ} \mathrm{C}$ & + & + & + & - & + & + & $\mathrm{w}$ & + & + & + & + \\
\hline $37^{\circ} \mathrm{C}$ & + & + & + & - & + & - & + & + & $\mathrm{w}$ & + & + \\
\hline $40{ }^{\circ} \mathrm{C}$ & + & + & - & - & - & - & - & $\mathrm{w}$ & + & + & + \\
\hline Optimum growth temperature $\left({ }^{\circ} \mathrm{C}\right)$ & 30 & 30 & 30 & 20 & 25 & 25 & 20 & 30 & 25 & $30-37$ & 27 \\
\hline Casein & - & - & - & $\mathrm{NA}$ & - & - & $\mathrm{w}$ & $\mathrm{w}$ & - & - & NA \\
\hline Gelatin & - & + & - & + & + & + & + & + & - & + & + \\
\hline Starch & - & - & - & + & - & - & $\mathrm{w}$ & - & - & - & + \\
\hline Tween 80 & - & - & - & $\mathrm{NA}$ & - & - & NA & NA & $\mathrm{w}$ & - & NA \\
\hline Tyrosine & - & - & - & $\mathrm{NA}$ & + & NA & - & NA & + & - & NA \\
\hline Nitrate reduction & $\mathrm{NA}$ & - & + & - & + & + & - & + & + & - & - \\
\hline Deamination of phenylalanine & - & - & + & NA & NA & NA & + & NA & $\mathrm{w}$ & - & - \\
\hline \multicolumn{12}{|l|}{ Acid production from: } \\
\hline D-Glucose & - & - & - & - & - & + & + & NA & - & - & - \\
\hline D-Mannitol & - & - & - & - & - & + & - & NA & NA & - & - \\
\hline D-Xylose & - & - & - & - & - & + & - & $\mathrm{NA}$ & - & - & - \\
\hline
\end{tabular}

${ }^{*} \mathrm{LO}$, Light orange; $\mathrm{WH}$, white; BE, beige.

$\dagger \mathrm{R}$, Rod; S, spherical.

$\ddagger$, Central; ST, subterminal; T, terminal.

\$Data for 11 strains.

$50 \mathrm{CH}$ and API 20NE galleries according to the instructions of the manufacturer (bioMérieux). DNA-DNA hybridization experiments were performed with CCUG $53915^{\mathrm{T}}$ and the type strains of $S$. koreensis and S. soli, and with strain CCUG $53480^{\mathrm{T}}$ and $S$. saromensis $\mathrm{HG} 645^{\mathrm{T}}$ and the type strain of S. koreensis according to the method of Ziemke et al. (1998). DNA-DNA similarity values between strains were as follows: CCUG $53915^{\mathrm{T}}$ and S. koreensis DSM $16921^{\mathrm{T}}, 28.0 \%$; CCUG $53915^{\mathrm{T}}$ and S. soli DSM $16920^{\mathrm{T}}$, $30.2 \%$; CCUG $53480^{\mathrm{T}}$ and S. saromensis $\mathrm{HG} 645^{\mathrm{T}}, 36.1 \%$; and CCUG $53480^{\mathrm{T}}$ and S. koreensis $\mathrm{F} 73^{\mathrm{T}}, 43.1 \%$.

Peptidoglycan types, quinone systems, and fatty acid and polar lipid profiles, as well as 16S rRNA analyses, show unambiguously that strains CCUG $53915^{\mathrm{T}}$ and CCUG $53480^{\mathrm{T}}$ are affiliated with the genus Sporosarcina. On the basis of the observed phenotypic differences, the results of the DNA-DNA pairing studies and differences in 16S rRNA gene sequences, two novel Sporosarcina species are proposed.

\section{Description of Sporosarcina contaminans sp. nov.}

Sporosarcina contaminans (con.ta'mi.nans. L. part. adj. contaminans contaminating, polluting, isolated as a contaminant of an industrial clean-room floor).

Cells are Gram-positive, strictly aerobic, motile rods (0.8$1.0 \times 2.0-3.0 \mu \mathrm{m})$. Spherical endospores are formed in a terminal position. Colonies grown on TSA are circular, convex and beige. Optimal temperature for growth is $30{ }^{\circ} \mathrm{C}$; growth occurs at $15-50{ }^{\circ} \mathrm{C}$, but not at 5 or $55^{\circ} \mathrm{C}$. Optimal 
$\mathrm{pH}$ for growth is 7.0-8.0; growth occurs at $\mathrm{pH} 6.5-10.5$. $\mathrm{NaCl}$ is not required for growth, but can be tolerated up to $9 \%(\mathrm{w} / \mathrm{v})$. Positive for catalase and oxidase activities. Gelatin and starch are not hydrolysed. $\mathrm{H}_{2} \mathrm{~S}$, indole and acetoin are not produced. Nitrate is not reduced. Negative for urease, gelatinase, $\beta$-galactosidase, arginine dihydrolase, lysine decarboxylase, ornithine decarboxylase, tryptophan deaminase and citrate utilization. No acid formation from sugars is observed. Sugar compounds in the API 50CH gallery are not utilized. Some organic acids, such as pyruvate, fumarate and L-malate, are utilized according to the method of Kämpfer et al. (1991). Further physiological data are indicated in Table 1 . The peptidoglycan is of type A $4 \alpha$ L-Lys-D-Glu and the major menaquinone is MK-7. The polar lipid profile consists of the major lipids diphosphatidylglycerol, phosphatidylglycerol and phosphatidylethanolamine. Major fatty acids are anteiso- $\mathrm{C}_{15: 0}$ and iso- $\mathrm{C}_{15: 0}$; iso- $\mathrm{C}_{14: 0}$, iso- $\mathrm{C}_{17: 0}$ and anteiso- $\mathrm{C}_{17: 0}$ are also detected.

The type strain is CCUG $53915^{\mathrm{T}}\left(=\mathrm{DSM} 22204^{\mathrm{T}}\right.$ ), isolated as a contaminant from an industrial clean-room floor in Göteborg, Sweden.

\section{Description of Sporosarcina thermotolerans sp. nov.}

Sporosarcina thermotolerans (ther.mo.to'ler.ans. Gr. n. thermê heat; L. part. adj. tolerans tolerating; N.L. part. adj. thermotolerans heat-tolerating).

Cells are Gram-positive, strictly aerobic, non-motile rods $(0.8-1.0 \times 2.0-3.0 \mu \mathrm{m})$. Spherical endospores are formed in a terminal position. Colonies grown on TSA are circular, convex and beige. Optimal temperature for growth is 30 $37^{\circ} \mathrm{C}$; growth occurs at $15-50{ }^{\circ} \mathrm{C}$, but not at 5 or $55^{\circ} \mathrm{C}$. Optimal $\mathrm{pH}$ for growth is 7.0-8.0; growth occurs at $\mathrm{pH}$ 6.5-8.5. $\mathrm{NaCl}$ is not required for growth, but can be tolerated up to $3 \%(\mathrm{w} / \mathrm{v})$. Positive for catalase and oxidase activities. Gelatin and starch are hydrolysed. $\mathrm{H}_{2} \mathrm{~S}$, indole and acetoin are not produced. Nitrate is not reduced. Positive for gelatinase activity. Negative for urease, $\beta$ galactosidase, arginine dihydrolase, lysine decarboxylase, ornithine decarboxylase, tryptophan deaminase and citrate utilization. Acid is not produced from carbohydrates. No sugars or other compounds in the API $50 \mathrm{CH}$ gallery are utilized. The peptidoglycan is of type A $4 \alpha$ L-Lys-D-Glu and the major menaquinone is MK-7. The polar lipid profile consists of the major lipids diphosphatidylglycerol, phosphatidylglycerol and phosphatidylethanolamine. Major fatty acids are anteiso- $\mathrm{C}_{15: 0}$, iso- $\mathrm{C}_{15: 0}$ and iso- $\mathrm{C}_{14: 0}$.

The type strain is CCUG $53480^{\mathrm{T}}\left(=\mathrm{DSM} 22203^{\mathrm{T}}\right)$, isolated from a human blood sample of a 54-year-old woman in Göteborg, Sweden.

\section{Acknowledgements}

We are grateful to Anika Wasner (DSMZ) and Gundula Will for excellent technical assistance and $16 \mathrm{~S}$ rRNA gene sequencing. We thank Dr S.-Y. An for providing the type strain of S. saromensis.

\section{References}

An, S.-Y., Haga, T., Kasai, H., Goto, K. \& Yokota, A. (2007). Sporosarcina saromensis sp. nov., an aerobic endospore-forming bacterium. Int J Syst Evol Microbiol 57, 1868-1871.

Claus, D. \& Fahmy, F. (1986). Genus Sporosarcina Kluyver and van Niel 1936, 401 ${ }^{\mathrm{AL}}$. In Bergey's Manual of Systematic Bacteriology, vol. 2, pp. 1202-1206. Edited by P. H. A. Sneath, N. S. Mair, M. E. Sharpe \& J. G. Holt. Baltimore: Williams \& Wilkins.

Claus, D., Fahmy, F., Rolf, H. J. \& Tosunoglu, N. (1983). Sporosarcina halophila sp. nov., an obligate, slightly halophilic bacterium from salt marsh soils. Syst Appl Microbiol 4, 496-506.

Collins, M. D., Pirouz, T., Goodfellow, M. \& Minnikin, D. E. (1977). Distribution of menaquinones in actinomycetes and corynebacteria. J Gen Microbiol 100, 221-230.

Gerhardt, P., Murray, R. G. E., Wood, W. A. \& Krieg, N. R. (editors) (1994). Methods for General and Molecular Bacteriology. Washington, DC: American Society for Microbiology.

Groth, I., Schumann, P., Weiss, N., Martin, K. \& Rainey, F. A. (1996). Agrococcus jenensis gen. nov., sp. nov., a new genus of actinomycetes with diaminobutyric acid in the cell wall. Int J Syst Bacteriol 46, 234239.

Kämpfer, P. \& Kroppenstedt, R. M. (1996). Numerical analysis of fatty acid patterns of coryneform bacteria and related taxa. Can J Microbiol 42, 989-1005.

Kämpfer, P., Steiof, M. \& Dott, W. (1991). Microbiological characterization of a fuel-oil contaminated site including numerical identification of heterotrophic water and soil bacteria. Microb Ecol 21, 227-251.

Kämpfer, P., Dreyer, U., Neef, A., Dott, W. \& Busse, H.-J. (2003). Chryseobacterium defluvii sp. nov., isolated from wastewater. Int J Syst Evol Microbiol 53, 93-97.

Kluyver, A. J. \& van Niel, C. B. (1936). Prospects for a natural system of classification of bacteria. Zentralbl Bakteriol Parasitenkd Infektionskr Hyg Abt II 94, 369-403.

Krishnamurthi, S., Bhattacharya, A., Mayilraj, S., Saha, P., Schumann, P. \& Chakrabarti, T. (2009). Description of Paenisporosarcina quisquiliarum gen. nov., sp. nov., and reclassification of Sporosarcina macmurdoensis Reddy et al. 2003 as Paenisporosarcina macmurdoensis comb. nov. Int $J$ Syst Evol Microbiol 59, 1364-1370.

Kwon, S.-W., Kim, B.-Y., Song, J., Weon, H.-Y., Schumann, P., Tindall, B. J., Stackebrandt, E. \& Fritze, D. (2007). Sporosarcina koreensis sp. nov. and Sporosarcina soli sp. nov., isolated from soil in Korea. Int J Syst Evol Microbiol 57, 1694-1698.

Lane, D. J. (1991). 16S/23S rRNA sequencing. In Nucleic Acid Techniques in Bacterial Systematics, pp. 115-175. Edited by E. Stackebrandt \& M. Goodfellow. Chichester, UK: Wiley.

Ludwig, W., Strunk, O., Westram, R., Richter, L., Meier, H., Yadhukumar, Buchner, A., Lai, T., Steppi, S. \& other authors (2004). ARB: a software environment for sequence data. Nucleic Acids Res 32, 1363-1371.

MacKenzie, S. L. (1987). Gas chromatographic analysis of amino acids as the $N$-heptafluorobutyryl isobutyl esters $J$ Assoc Off Anal Chem 70, 151-160.

Minnikin, D. E., Collins, M. D. \& Goodfellow, M. (1979). Fatty acid and polar lipid composition in the classification of Cellulomonas, Oerskovia and related taxa. J Appl Bacteriol 47, 87-95.

Nakamura, L. K. (1984). Bacillus psychrophilus sp. nov., nom. rev. Int J Syst Bacteriol 34, 121-123. 
Olsen, G. J., Matsuda, H., Hagstrom, R. \& Overbeek, R. (1994). FASTDNAML: a tool for construction of phylogenetic trees of DNA sequences using maximum likelihood. Comput Appl Biosci 10, 41-48.

Pruesse, E., Quast, C., Knittel, K., Fuchs, B. M., Ludwig, W., Peplies, J. \& Glöckner, F. O. (2007). SILVA: a comprehensive online resource for quality checked and aligned ribosomal RNA sequence data compatible with ARB. Nucleic Acids Res 35, 7188-7196.

Reddy, G. S. N., Matsumoto, G. I. \& Shivaji, S. (2003). Sporosarcina macmurdoensis sp. nov., from a cyanobacterial mat sample from a pond in the McMurdo Dry Valleys, Antarctica. Int J Syst Evol Microbiol 53, 1363-1367.

Rüger, H.-J. (1983). Differentiation of Bacillus globisporus, Bacillus marinus comb. nov., Bacillus aminovorans, and Bacillus insolitus. Int J Syst Bacteriol 33, 157-161.

Schleifer, K. H. (1985). Analysis of the chemical composition and primary structure of murein. Methods Microbiol 18, 123-156.

Schleifer, K. H. \& Kandler, O. (1972). Peptidoglycan types of bacterial cell walls and their taxonomic implications. Bacteriol Rev 36, 407-477.
Tamura, K., Dudley, J., Nei, M. \& Kumar, S. (2007). MEGA4: Molecular Evolutionary Genetics Analysis (MEGA) software version 4.0. Mol Biol Evol 24, 1596-1599.

Yoon, J.-H., Lee, K.-C., Weiss, N., Kho, Y. H., Kang, K. H. \& Park, Y.-H. (2001). Sporosarcina aquimarina sp. nov., a bacterium isolated from seawater in Korea, and transfer of Bacillus globisporus (Larkin and Stokes 1967), Bacillus psychrophilus (Nakamura 1984) and Bacillus pasteurii (Chester 1898) to the genus Sporosarcina as Sporosarcina globispora comb. nov., Sporosarcina psychrophila comb. nov. and Sporosarcina pasteurii comb. nov., and emended description of the genus Sporosarcina. Int J Syst Evol Microbiol 51, 10791086.

Yu, Y., Xin, Y.-H., Liu, H.-C., Chen, B., Sheng, J., Chi, Z.-M., Zhou, P.-J. \& Zhang, D.-C. (2008). Sporosarcina antarctica sp. nov., a psychrophilic bacterium isolated from the Antarctic. Int J Syst Evol Microbiol 58, 2114-2117.

Ziemke, F., Höfle, M. G., Lalucat, J. \& Rosselló-Mora, R. (1998). Reclassification of Shewanella putrefaciens Owen's genomic group II as Shewanella baltica sp. nov. Int J Syst Bacteriol 48, 179-186. 